\title{
Red Allure and the Crimson Blindfold
}

\section{Geremie Barmé}

\section{OpenEdition}

\section{Journals}

\section{Electronic version}

URL: http://journals.openedition.org/chinaperspectives/5859

DOI: 10.4000/chinaperspectives.5859

ISSN: 1996-4617

\section{Publisher}

Centre d'étude français sur la Chine contemporaine

\section{Printed version}

Date of publication: 4 June 2012

Number of pages: $29-40$

ISSN: 2070-3449

\section{Electronic reference}

Geremie Barmé, «Red Allure and the Crimson Blindfold », China Perspectives [Online], 2012/2 | 2012

Online since 30 June 2015, connection on 28 October 2019. URL : http://journals.openedition.org/ chinaperspectives/5859; DOI : 10.4000/chinaperspectives.5859 


\title{
Red Allure and
}

\section{the Crimson Blindfold}

GEREMIE R. BARMÉ*

\begin{abstract}
This essay takes as its starting point the precipitous fall of Bo Xilai in March 2012 and discusses the context of the abiding significance of China's red legacies, in particular Maoism, in understanding the People's Republic of China today. While thinkers labour to salvage Marxism, the red legacy constitutes a body of cultural, intellectual, and linguistic practices that are profoundly ingrained in institutional behaviour in China. This study explores to what extent this version of the red legacy leeches out the power of other modes of leftleaning critique and independent thought, and abets the party-state in its pursuit of a guided, one-party neo-liberal economic agenda.
\end{abstract}

KEYWORDS: Bo Xilai, Wang Lijun, Mao Zedong, Zhang Musheng, red culture, Maoism, Chinese history, neo-liberalism, New Left, Children of Yan'an.

$\mathrm{T}$ his essay is part of a larger project that relates to "The China Story," (1) but herein I will limit myself to a consideration of a few areas in which I believe we can find traces of the abiding, and beguiling, heritage of the High-Maoist era and state socialism in today's China. I review some previously published work, some of which has appeared under various scholastic guises as well as in the virtual pages of the e-journal China Heritage Quarterly (www.chinaheritagequarterly.org). (2)

In a number of interconnected spheres a nuanced understanding of what have been called "red legacies" in China as well as more broadly can continue to enliven discussions of contemporary history, thought, culture, and politics. In the following I will focus on recent events before offering in turn some observations on history, the Maoist legacy, and academic engagement with the People's Republic.

Over the years, I have argued that the aura of High Maoism (1949-78) has continued to suffuse many aspects of thought, expression, and behaviour in contemporary China. ${ }^{(3)}$ This is not merely because the party-state of the People's Republic still formalistically cleaves to the panoply of Marxism-Leninism-Mao Zedong Thought (which, of course, it has elaborated through the addition of Deng Xiaoping Theory, Jiang Zemin's Three Represents, and Hu Jintao's View on Scientific Development). I would argue that, just as High Maoism was very much part of global revolutionary discourse and thinking in the twentieth century, so in the post-Mao decades its complex legacies, be they linguistic, intellectual, charismatic, or systemic, continue to enjoy a purchase. Furthermore, I support a view that an understanding of Maoism in history and over time, both in terms of empirical reality and in the context of memory, as well as an appreciation of its lingering allure, remains crucial if we are to gain an appreciation of the "real existing socialism" in the People's Republic today.

\section{The red patrimony}

It is important to begin by situating the "Red moment" within the context of an extended, and changing, historical narrative. While some important recent work has noted the "long tail" of Maoist-era institutional practice, ${ }^{(4)}$
I would further affirm earlier scholarship that locates the origins and evolution of what would become High Maoism from the 1950s in cultural and political genealogies of the late-Qing and Republican eras. ${ }^{(5)}$ In addition to

An earlier version of this essay was written for "Red Legacies in China" a conference at Harvard University, 2-3 April 2010, organised by Jie Li 李洁 and Enhua Zhang 张恩华 and jointly sponsored by the Chiang Ching-Kuo Foundation Inter-University Center for Sinology, the Harvard-Yenching Institute, and the Fairbank Center for Chinese Studies. For a report on that conference by the organisers, see: www.chinaheritagequarterly.org/scholarship.php?searchterm $=022$ conference. inc\&issue =022 (consulted on 10 May 2012). I am grateful to Sebastian Veg for his editorial guidance and to the two anonymous reviewers of an earlier draft of this work. I would also like to acknowledge Chris Buckley's contribution to my understanding of Chongqing, the model, and its camp-followers.

1. "The China Story" is a web-based initiative of the Australian Centre on China in the World (CIW) launched in 2012 that includes: The China Story Lexicon, China Story Yearbook, and a China Story Archive produced by CIW in collaboration with Danwei Media in Beijing.

2. For some of my essays relevant to this topic, see: "Time's Arrows: Imaginative Pasts and Nostalgic Futures," in Gloria Davies (ed.), Voicing Concerns: Contemporary Chinese Critical Inquiry, Boulder, Rowman \& Littlefield, 2001, pp. 226-57; "The Revolution of Resistance," in Elizabeth J. Perry \& Mark Selden (eds.), Chinese Society: Change, Conflict and Resistance, London, Routledge, Taylor \& Francis Group, 2000, pp. 47-70 (rev. 2004 \& 2010); "I'm so Ronree," The China Journal, vol. 55, 2006, pp. 128-39; The Forbidden City, London UK, Profile Book, 2008 (2009, 2012); "Beijing, a garden of violence," Inter-Asia Cultural Studies, vol. 9, no. 4, 2008, pp. 612-639; "China's Flat Earth: History and 8th August 2008," The China Quarterly, vol. 197, 2009, pp. 64-86'; "Beijing reoriented, an Olympic Undertaking," in Mary Farquhar (ed.), 21st Century China:Views from Australia, Cambridge (UK) Scholars Publishing, 2009, pp. 1-33; "For Truly Great Men, Look to This Age Alone was Mao Zedong a New Emperor?" in Timothy Cheek (ed.), A Critical Introduction to Mao, Cambridge University Press, New York, 2010, pp. 243-272; and "The Children of Yan'an: New Words of Warning to a Prosperous Age 盛世新危言," Chinese Heritage Quarterly, no. 26, June 2011, http://chinaheritagenewsletter.anu.edu.au/features.php? searchterm=026_yanan.inc\&issue =026 (consulted on 10 May 2012). For an early book devoted in part to these issues, see Shades of Mao: The posthumous career of the Great Leader (Armonk, NY, M.E. Sharpe, 1996, 321 pages); and for a work that notes the abiding legacies of the Maoist era during the 1980s and in particular during the Protest Movement of 1989, see the narration of The Gate of Heavenly Peace (Boston, 1995) at www.tsquare.tv, of which I was the principal author (consulted on 10 May 2012).

3. I would suggest a simple division of Maoism into: a pre-1949 form; that of High State Maoism when the complex body of thinking, policies, and personality cult held sway in China from 1949 until the end of 1978 (and the launching of the reform era); the 1978-89 decade of contestation; the 1989-99 decade of recalibration; and the 1999- era in which Maoist and Marxist legacies have found new champions both inside and outside of Chinese officialdom. Such a schema is but a crude convenience.

4. See, for example, Sebastian Heilmann and Elizabeth J. Perry (eds.), Mao's Invisible Hand: The Political Foundations of Adaptive Governance in China, Cambridge (MA), Harvard University Asia Center, 2011.

5. Elizabeth Perry's new work on the miners of Anyuan offers a particular account of the domestication of revolution in China. See Elizabeth J. Perry, Anyuan: Mining China's Revolutionary Tradition, Berkeley (CA), University of California Press, 2012 (forthcoming). 

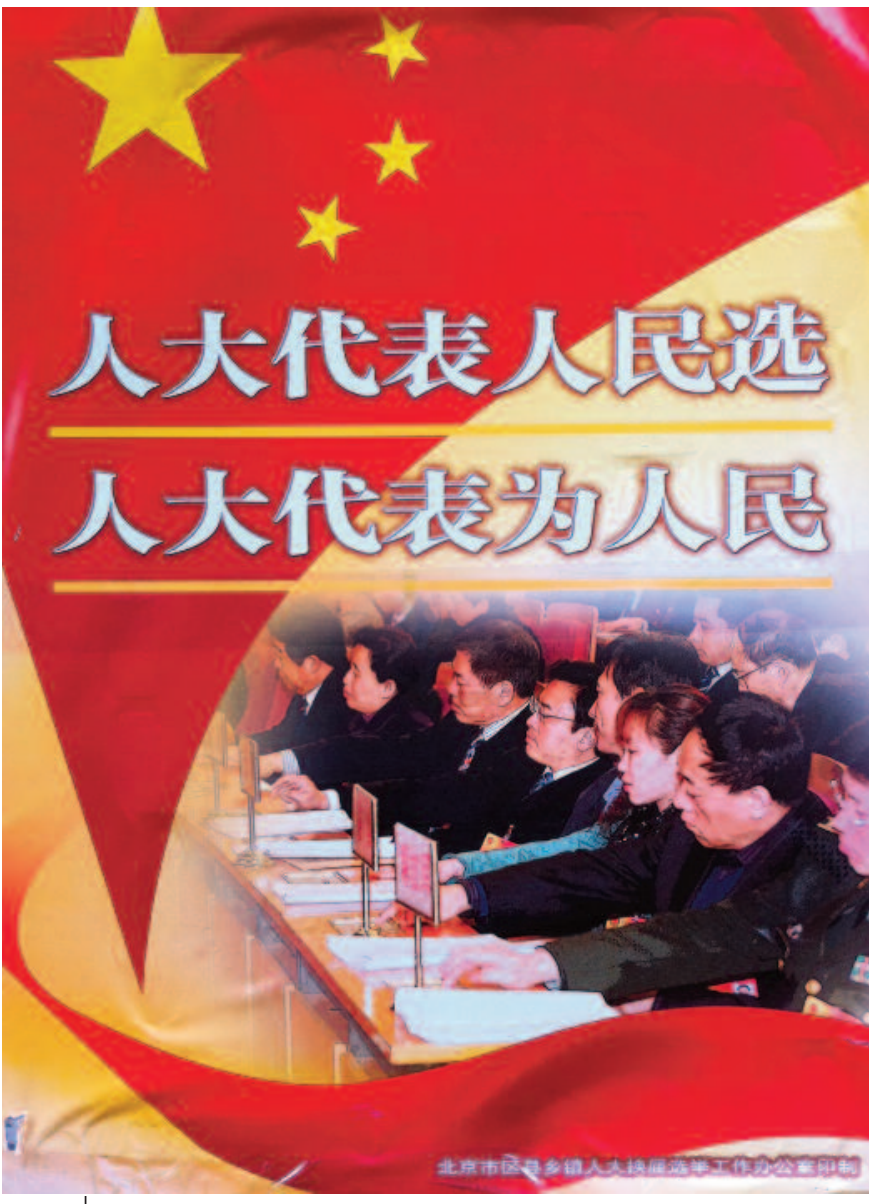

Poster promoting the Party's guided democracy, a Maoist mirage. ๑ G.R. Barmé

this age of revolution we should also be mindful of a longer and overlapping age of reform, one that to all intents and purposes has enjoyed a longue durée: from the externally generated and autocratically imposed reforms, or self-strengthening of the Tongzhi Restoration dating from 1860, through to the Open Door and Reform formally initiated by the Chinese Communist Party in late 1978.

When discussing China's historical legacy we are usually invited by the Chinese party-state to accept a certain narrative arc and its particular official articulation. (6) It is the story not of Chinese greatness as much as the connected tale of the decline in power, economic might, and unity of the Chinese world from the eighteenth century, through the century of humiliation (roughly 1840-1949) and the birth of a New China and the two acts of liberation (1949 and 1978). This culminates in the present with the "great renaissance of the Chinese nation" (Zhonghua minzude weida fuxing 中华 民族的伟大复兴) formally announced by Party General Secretary liang Zemin a decade ago and repeatedly affirmed by General Secretary Hu Jintao on the occasion of the celebration of the sixtieth anniversary of the People's Republic as well as when he marked the centenary of the 1911 Xinhai Revolution on 9 October 2011. (7) It is in this connected narrative that "The China Story" (Zhongguode gushi 中国的故事), itself a relatively recent conceit, has been concocted. (8) It is a story that has been interwoven intimately with the grand romantic narrative of communism. This narrative speaks to the history of the Party in the context of national revolution and independence; it cleaves to Mao Zedong (and a panoply of lesser leaders) as well as many aspects of his career, thought, and politics. Although the Communist Party-centric version of that narrative may appear to many to be politically bankrupt in all but name, the appeal of an overarching existential rationale for the power-holders, and indeed for people of various backgrounds who have been immersed in the carefully modulated party-state account of China's past, remains undiminished.

One of the most abiding legacies of the red era, and one particularly attractive for its advocates regardless of their present political persuasion, is the paradigm of the Cold War. In the eternal present of Cold War attitudes and rhetoric the panoply of devices carefully cultivated during the era of class struggle is easily translated into the tensions between the People's Republic of China and its neighbours as well as other developed nations today. The rhetorical landscape so comfortably traversed by the party-state and those in its thrall (from state think tank apparatchiki and a swarm of leftleaning academics to semi-independent media writers) also feeds the mimetic grandstanding of the other side in any given stoush.

Since 2009, rhetorical clashes of this kind have revolved around such areas as: climate change, US arms sales to Taiwan, the valuation of the Renminbi, Internet freedom, territorial issues in the South China Sea, and ongoing disturbances in Tibet and Xinjiang. ${ }^{(9)}$ These issues - and here I am concerned with Chinese rhetoric, not the substantive matters involving different national and economic interests - the default position of the Chinese partystate remains that of the early Maoist days, when conspiracy theories, class struggle, and overblown rhetorical grandstanding formed the backdrop to any official stance. ${ }^{(10)}$ Of course, any discussion of rhetorical opposition cannot detract from real clashes of national interests, worldviews, or political and economic systems.

The Maoist past continues to shape perceptions and discursive practices in the cultural-linguistic realm of China today. Elsewhere, I have noted that the language of "totalitarianism" (that is holistic or totalising systems in which the party-state - in particular its leaders and theorists - attempts to dominate and determine ideological visions and linguistic practices, as well as social, political, and economic policy) as it evolved over many years came to operate according to rules and an internal logic that aid and abet a

6. See, for example, William A. Callahan, China: The Pessoptimist Nation, New York, Oxford University Press, 2009.

7. See, for example, such analyses as: "'Sange daibiao' yu Zhonghua minzu weidade fuxing," 8 February 2002, www.bjqx.org.cn/qxweb/n807c5.aspx (consulted on 11 May 2012); and "Zhengque lijie Zhonghua minzude weida fuxing," 27 January 2007, www.bjqx.org.cn/qxweb/n7499c5.aspx (consulted on 11 May 2012). Hu jintao used the expression "Chinese national revival" (Zhonghua minzu fuxing) 23 times during his 9 October 2011 Xinhai speech. See "Hu Jintao 23 ci ti Zhonghua minzu fuxing, minzu fuxing bixu zhaodao zhengque daolu," in Nanfang ribao, 10 October 2011, http://politics.people.com.cn/GB/1026/15842000.html (consulted on 11 May 2012). For a recent comment on various aspects of this narrative as generated in China and internationally, see William A. Callahan, "Sino-speak: Chinese Exceptionalism and the Politics of History," The Journal of Asian Studies, vol. 71, no. 1, February 2012, pp. 1-23.

8. For more on this, see my analysis of the Opening Ceremony of the 2008 Beijing Olympics, "China's Flat Earth: History and 8 August 2008," The China Quarterly, vol. 197, March 2009, pp. 64-86; and, my "Telling Chinese Stories" presented at The University of Sydney, 1 May 2012.

9. Although US-based academic audiences will invariably see things through the particular (dare I say "distorting"?) prism of US-China-specific relations, for those of us in the Antipodes the various kerfuffles in 2009 involving the Sino-Australian relationship over the aluminium corporation of China Chinalco's investment plans, Stern Hu's arrest in Shanghai (and March 2010 trial), and the visit of the Uyghur activist Rebiya Kadeer to Melbourne, are more salient. For more on this, see China Story Yearbook 2012: Red Rising, Red Eclipse, Canberra, Australian Centre on China in the World (ANU), 2012

10. See, for example, Qiang Zhai, "1959: Preventing Peaceful Evolution," China Heritage Quarterly, no. 18, June 2009, www.chinaheritagequarterly.org/features.php?searchterm=018_1959preventingpeace. inc\&issue=018 (consulted on 11 May 2012); and, my essay "The Harmonious Evolution of Information in China," China Heritage Quarterly, no. 21, March 2010, www.chinaheritagequarterly.org/articles.php?searchterm=021_peacefulevolution.inc\&issue=021 (consulted on 11 May 2012). 
thought process conducive to its continued sway. ${ }^{(11)}$ In the past this attempt at Gleichschaltung, that is the coordination or "intermeshing" of the inner and outer individual, as well as the various arms and practices of governance, was part of the construction of the socialist enterprise and the "new socialist man." Today, the situation is far more complex as elements of socialism are melded with neo-liberalism, and the New China Newspeak of the party-state has been injected with the discursive practices of global managerialism. ${ }^{(12)}$

In the decades of its ascendancy, as well in the subsequent long years of tenacious reform, the totalitarian in China has exhibited an intriguing versatility, one whereby it has continued to "commodify" or "domesticate" to its particular ends culture, ideas, and even oppositionist forces. ${ }^{(13)}$

We may well ask, however, has revolutionary politics, or even the potency of left-leaning ideas, been entirely evacuated from this story today? Has the neo-liberal turn of Chinese statist politics of recent decades created less a story of revolutionary potential (or even leftist resistance) and more one that offers an account of self-interest constructed around a concocted "Chinese race," an account the main concern of which is a nationalistic rise on the world stage? Or, do the various red legacies that date from the Republican era (be they communist, socialist, or social-democratic) contribute something more than a turn of phrase, a glossy overlay of Party culture, and a coherent (and now often glib) account of national decline and revival to China's political discourse and national mission? If so, then how does the leftist legacy distinguish itself from a failed Maoism? Or is Maoism and its panoply of language and practices the only viable source of resistance besides the discourses of universalism, as well as economic and human rights in China today?

In discussing the past it is of vital importance to appreciate motivating ideas and ideals; by the same token we should be wary of those who would separate for their convenience theory from historical reality (even though the details of that reality themselves may be contested). Some writers on contemporary China and its tangle of traditions find it enticing to engage in what could be called a "strategic disaggregation" of the ideological/ theoretical from the historical/ lived. Without doubt, it is important for thoughtful academics to challenge the crude narratives related to modern Chinese history, be they authored by the Chinese party-state, by the international media, or indeed by a Cold War-inflected academic world. However, in the process equally ham-fisted attempts to "recuperate" elements of Maoism or Chinese-inflected Marxism-Leninism in the context of the oneparty state can too easily allow people to champion abstract ideas clear of the bloody and tragic realities of the past. Similarly, to privilege Maoism while overlooking the other leftist traditions, the "paths not taken" due to the hegemony of the Chinese Communist Party, is to view the past with the same kind of ideological bias of which pro-Maoist writers accuse their liberal and neo-liberal opponents.

Below, in the first instance, I touch briefly on recent events and their background before going on to consider historical narrative, cultural phenomena, and intellectual careerism.

\section{A red star falls over China: Lessons from Chongqing}

The red patrimony - and indeed it is mostly the construction of male thinkers, activists, and power-holders - contains within it a whole range of intellectual artefacts from various points in China's revolutionary theory and practice. The generation of "enemies" (pace Carl Schmitt and his con- temporary acolytes) and the atmospherics of plots and conspiracies are still central to the way that the Chinese Communist Party channels and responds to the spectres of the past. Although this formerly underground political party has recast itself as a legitimate government (zhizhengdang 执政党) with all the paraphernalia of state power, to this day its internal protocols and behaviour recall all too frequently its long history as a covert, highly secretive, and faction-ridden organisation. Even under Mao, some commentators called China a "mafia-state." This aspect of the party-state was thrown into sharp relief in February 2012 when the former deputy mayor of Chongqing, Wang Lijun 王立军, a man famed for a time for having led the attack on that city's own "mafias," was ordered to undergo a euphemistically termed "extended period of therapeutic rest" (xiujiashi zhiliao 休假式治疗) following his appearance at, and subsequent disappearance from, the US consulate in Chengdu, Sichuan Province (subsequently, "treatment" was revised to become detention and investigation). The next month, on 15 March, his erstwhile local Party leader, Bo Xilai 薄熙来, was dismissed from his various positions and put under investigation.

On 14 March 2012, a day before the sensational news of Bo Xilai's fall was announced, the Chinese Premier Wen Jiabao, speaking at what would be his last press conference as the head of China's government, twice referred to the 1981 Communist Party decision on "certain historical questions." (14) That document is one of key importance for an understanding of post-Mao Chinese politics; it also provides the ideological rationale for China's post-1978 economic reforms. In that carefully worded text, the socio-economic policies that had underpinned the Mao era, including the Great Leap Forward and the Cultural Revolution, were formally negated. In March 2012, Wen referred to the 1981 decision in the following way:

I want to say a few words at this point, since the founding of the People's Republic China, under the leadership of the Party and the government, our country's modernisation drive has made great achievements. Yet at the same time, we've also taken detours and have learnt hard lessons. Since the Third Plenum of the 11th CPC Central Committee [in December 1978], in particular since the central authorities took the decision on the correct handling of relevant historical issues, we have established the line of thinking and that we should free our minds and seek truth from facts and we have formulated the basic guidelines of our Party. In particular, we've taken the major decision of conducting reform and opening up in China, a decision that's crucial for China's future and destiny.

What has happened shows that any practice that we take must be based on the experience and lessons we've gained from history and it must serve the people's interests. The practice that we take must

11. See Michael Schoenhals, Doing Things with Words in Chinese Politics: Five Studies, Berkeley (CA), Institute of East Asian Studies (University of California), China Research Monograph, 1992; and, Anne-Marie Brady, Marketing Dictatorship: Propaganda and Thought Work in Contemporary China, Boulder (CO), Rowman \& Littlefield, 2008.

12. For an extended essay on New China Newspeak, see the entry in the China Heritage Glossary, China Heritage Quarterly, no. 29, March 2012, www.chinaheritagequarterly.org/glossary.php? searchterm=029_xinhua.inc\&issue $=029$ (consulted on 15 May 2012)

13. This is the particular focus of my 1999 book In the Red: On contemporary Chinese culture, New York, Columbia University Press.

14. "Resolution on Certain Questions in the History of our Party Since the Founding of the People's Republic of China (Adopted by the Sixth Plenary Session of the Eleventh Central Committee of the Communist Party of China on 27 June 1981)," available online at: www.marxists.org/subject/ china/documents/cpc/history/01.htm (consulted on 11 May 2012). 
be able to stand the test of history and I believe the people fully recognise this point and I have full confidence in our future. ${ }^{(15)}$

Over a year before Bo Xilai was put under investigation for breaching Party discipline, there were overt signs that ideological contestation and a concomitant power struggle were well underway. Since the last major public power struggle within the Chinese Communist Party over two decades ago in 1989, it has become an accepted view of China's particular brand of oneparty consensual authoritarianism that prior to any leadership change jostling for position within the top echelon of the hierarchy takes a number of forms. While it is all but impossible to track effectively the backroom dealings, the power plays, and the political feints involved in what is a byzantine process, the media still provide some indication of the nature of intra-party tussles. Zhongnanhai-ology, however, remains at best an imaginative art. Nonetheless, given the volubility of various critics of the Party since 2009, by early 2011 observers were wondering what had happened to the usually outspoken organs of Party Central.

In late May 2011, the Party did finally make itself heard over the din of fraught contestation. In an opinion piece published by the Central Disciplinary Commission on 25 May, Party members were warned to obey "political discipline" and to cease henceforth from offering unsolicited and wayward views on China's political future. It declared that a "profound political struggle" currently confronted the Party; it was time to silence idle speculation and furthermore it was necessary to reiterate Party General Secretary Hu Jintao's "Six Absolute Interdictions" (liuge juebu yunxu 六个决不允许) for Party members - basically, follow the Party line and do not engage in public discussions or offer personal opinions; do not fabricate or spread political gossip; and do not leak state secrets or participate in illegal organisations. ${ }^{(16)}$

The document noted that there were those who were "pursuing their own agendas in regard to Party policy and requirements, all the while making a show of being in step with the Party; others have been taken in by various stories they pick up, indulge in idle speculation and generate 'political rumours'." Furthermore, it warned that dissenting Party voices were leading to (disruptive) non-Party and international speculation about the Communist Party's leadership and its future. In other words, it could damage the national economy. In 2011-12, the issues of the Maoist legacy were not matters merely of academic interest; they directly impinged on the party-state's succession plans and more broadly on contending agendas for China's future direction both at home and internationally. One particular area of contention related to how the Maoist past could, and indeed should, contribute to China's future.

\section{Metaphors of history: Rumours and factions}

More broadly, the events of Chongqing reveal a distinct political culture with its own specific history, one that reaches back into the High-Maoist, Republican, and imperial eras. It is significant that Bo Xilai's own promotion of red culture included "red reading" that encouraged officials and citizens to "read the classics" covering thinkers and works from all of these periods. As rumours circulated - and were energetically denied or dismissed by the authorities - one is reminded of previous episodes in Communist Party history during which rumour-mongering, talk of corruption, and the crushing of dissent have been rife. Of course, there is the earliest story related to the writer Wang Shiwei. A critic of Party privilege in the Yan'an period during the early 1940s, he was branded a Trotskyite and traitor. Eventually he was beheaded. (17)
Political rumours (zhengzhi yaoyan 政治谣言) featured during various crucial periods in the People's Republic as well, in particular during the Maoist years. Given the Party's control over the media and the secretive nature of its political processes, gossip and rumours have long been the stuff of informal comment on the issues of the day, and the means by which alternative accounts of Party rule circulate. For example, after the founding of the People's Republic, when Mao called on intellectuals and others to help the Party "rectify its work style" in light of criticisms of Party rule in the Eastern Bloc in 1956, many took advantage of the invitation to speak out against the secretive privileges and power of Party cadres. They, too, were silenced. In 1966, when Red Guard rebels were first allowed to attack the Party, they identified privilege, corruption, and abuse of power as one of the greatest enemies to the revolution. During this period of Party civil war it was word of mouth and big-character posters that were the common medium employed by individuals and groups to speculate and denounce. Again, around the time of Lin Biao's fall in 1971, there was a campaign against political hearsay involving Jiang Qing and her famous interviews with Roxanne Witke. Following Deng Xiaoping's fall in April 1976, the "strange talk and odd ideas" (qitan guailun 奇谈怪论) of July to September 1975 were denounced by the official media. Then, shortly after Mao's death, when there was a period of relatively free criticism of the purged Party leaders blamed for the mayhem of the Cultural Revolution, privilege and corruption were identified once more as the greatest threat. Another period of political speculation followed shortly thereafter at the time of the Xidan Democracy Wall in 1978-79, and again in 1988-89 leading up to 4 June, rumours and speculation were rife. During the 1989 nation-wide protests, some protesters released a detailed account of the connection between Party bureaucrats, their children, and the new business ventures that had sprung up during the early stages of reform. (One of the Party leaders named and blamed for the corrupt nexus between Party power, private enterprise, and global capital was Zhao Ziyang, later ousted as Party General Secretary.) Even from this cursory sketch we notice that intensified political gossip and official attempts to silence it have been the hallmarks of ruptures in Chinese life for over six decades. Thus, it was no surprise that, shortly following the announcement of disciplinary and legal investigations into Bo Xilai and his wife, Gu Kailai, in April 2012, the authorities announced a new push to quell political rumour-mongering. On 16 April, the People's Daily denied rumours of a coup and that military vehicles had been deployed in the capital; ${ }^{(18)}$ in the days that followed, a series of denials and articles decrying the malign influence of rumour-mongering were published both in the national and local media. ${ }^{(19)}$

The political culture of historical inference, or to use a formulation familiar from the period of High Maoism, "to use the past to satirise the present" (jiegu fengjin 借古讽今) or at least to use the past to reflect on the present

15. Reuters, "China Premier Wen Jiabao's comments at NPC press conference," www.reuters.com/article/2012/03/14/china-npc-highlights-idUSL4E8EE11K20120314 (consulted on 11 May 2012).

16. See "Jianjue weihu dangde zhengzhi jilü," http://opinion.people.com.cn/GB/14727703.html (consulted on 11 May 2012); and the independent commentary, www.chinese.rfi.fr/中国/20110525中纪委警告中共党员莫对重大政治问题”说三道四” (consulted on 11 May 2012).

17. See Dai Qing, "Wang Shiwei and 'Wild Lilies"' (Wang Shiweiyu "Yebaihehua'), the full text on www.cup-authors.com/daiqing/article.php?id=81 (consulted on 11 May 2012); and, Dai Qing, Wang Shiwei and "Wild Lilies": Rectification and purges in the Chinese Communist Party, 19421944, edited by David E. Apter and Timothy Cheek, translated by Nancy Liu and Lawrence R. Sullivan, documents compiled by Song Jinshou, Armonk (NY), M.E. Sharpe, 1994.

18. See "'Junche jinjing' yaoyan jiyi yingxiang wending," Renmin ribao, 16 April 2012, http://news.cn.yahoo.com/ypen/20120416/989582.html (consulted on 11 May 2012).

19. See for example, Zhang He, "'Yao renqing wangluo yaoyande shehui weihai'," Renmin ribao, 16 April 2012, http://news.q9.com/a/20120416/000160.htm (consulted on 11 May 2012), and so on. 
(yujin 喻今), is still familiar not only to writers who grew up in the days of Maoism and its official disavowal (1978-1980s), but also to writers today. One could argue that historical metaphors are part of the fabric of Chinese social and cultural life that far predate the Mao era. ${ }^{(20)}$ There is no doubt that finding esoteric meanings, clues to contemporary politics, messages for the masses, and so on in plays, novels, and movies was a central feature of Maoist-era politics and cultural life. During the post-Cultural Revolution disavowal of the politics of the purge and mass campaigns, this use of history and culture was decried as being a "historiography by [political] inference" (yingshe shixue 影射史学).

Despite this, in the penumbra of politics, a popular market for revelations about the inner workings of power continues to this day, something evident most recently in the wave of microblog comments on the Chinese Internet surrounding Bo Xilai, as well as his immediate and extended family.

Rumours have a venerable history in modern China. At the end of the Qing dynasty, for example, rumours about court politics abounded. They filled accounts known as "wild" or "untamed histories" (yeshi 野史); they provided an alternative to the formal records of the time. While the new Republican government would appoint a bureau to oversee a writing of a formal Qing history (a controversial and flawed enterprise that produced a Draft History of the Qing 清史稿), unofficial or "wild histories" proliferated. As the historian Harold Kahn has noted:

Official history adjusted the record to suit the needs of the court; unofficial history embroidered it to meet the tastes of a broader, less discriminating public. And it is this embroidered record which has formed the stable of much of China's popular historical thought. (21)

Shortly following the founding of the Republic of China in 1912, scabrous revelations about the inner workings of the defunct imperial court, as well as speculation regarding some of the most notorious incidents in the Qing dynasty, became the stuff of popular history writing and literature. There were, for example, stories about the rumoured marriage between the empress dowager Xiaozhuang 孝庄 ( d. 1688) and her brother-in-law Dorgon 多尔衷; details of the imperial prince Yinzhen's 胤祯 usurpation of the throne following the death of his father the Kangxi 康熙 emperor; hearsay to do with the Yongzheng 雍正 emperor's sudden demise; discussions about the questionable relationship between the minister Hešen 和珅 and the Qianlong 乾隆 emperor; details related to the invasion of the Forbidden City during the Jiaqing 嘉庆 reign; lascivious accounts of the addictions (and afflictions) of the youthful Tongzhi 同治 emperor in the 1870s; talk about what went on between the Empress Dowager and the eunuch Li Lianying 李莲英; dark mutterings surrounding the mysterious demise of the Guangxu 光绪 emperor (he predeceased the Empress Dowager by a day); and so on and so forth. What were illicit unofficial accounts in the past provided fodder for readers who had access to a booming publishing market, and with due consideration of the anti-Qing sentiment of the early Republic were anxious to see fun made of the defunct imperial masters while at the same time indulging in patriotic entertainment.

After 1949, the modern tradition of employing fiction or unofficial histories to reveal and speculate on the inner workings of China's rulers (not only dynastic, but also Republican, and eventually communist) continued to flourish, but in Hong Kong. That is until political relaxation, and a commercial publishing boom, transformed the media landscape in both China and Taiwan from the late 1970s. It is also perhaps hardly a coincidence that the first, albeit unsuccessful, cultural campaign of Maoist China was also one involved with historical verdicts and revelations of inner-court wrangling. This was the criticism that Mao Zedong launched shortly after the founding of the People's Republic of the Hong Kong film The Secret History of the Qing Court (Qinggong mishi 清宫秘史, 1948). (22)

The very culture of Emperors, Kings, Ministers, and Generals (di wang jiang xiang 帝王将相), as well as that of Talented Scholars and Beauties (caizi jiaren 才子佳人) collectively excoriated in the early years of the People's Republic and then actively denounced as part of the prelude to the Cultural Revolution era has, since the 1980s, become part of the mainstream once more. The production of Chinese historical costume dramas had previously been the province of TV and film-makers in Hong Kong and Taiwan. It was in the 1990s, however, as a result of voracious TV audiences and a political environment that was more willing to accept the previously excoriated "feudal" past, that numerous new accounts of the imperial era appeared in the form of "fanciful accounts" (xishuo 戏说) of emperors and empresses variously in their youth, at the height of their powers, and in their dotage. One of the first of these was the 1991 Taiwan-mainland coproduction A Fanciful Account of Qianlong (Xishuo Qianlong 戏说乾隆), a 41-part TV series about the Qianlong emperor's Tours of the South, based on a fictional account of the ruler's supposed exploits during three of his provincial progresses. (23) The "fanciful account" genre would eventually become a version of historical narrative characterised by semi- or completely farcical recountings of historical incidents, figures, or even past fictions for the sake of popular entertainment. Films and TV shows in this semi-parodic style would proliferate.

The recapturing of the past through such humorous and often lubricious fictions was liberating, and it has appeared to challenge the historical schema formalised during the early decades of the People's Republic. However, the actual story may be somewhat more complex. The rehabilitation of traditional history and storytelling, in particular in the form of popular history, since the advent of policies to promote "spiritual civilisation" first raised in 1979 and then pursued from the mid 1980s, serves well the political status quo. This is because the revival of the past is still, for the most part, expected to conform to the contours of national history as delineated in the Maoist-era temporal landscape. This timescape was itself developed over many decades on the basis of debates about Chinese history, periodisation, economic development, and social change, from the time of the New Culture Movement (roughly 1917-27). (24) Popular accounts of the imperial past aided the Party's overarching efforts to reintegrate the history of dynastic China, and the country's greatness, into the modern record and the broad narrative of national revival discussed earlier.

The popular fictionalisation of history, however, has hardly been limited to the dynastic past, nor has it simply accorded with official dictates. Film

20. This is a point made at length by Paul Cohen in his 2007 book Speaking to History: The Story of King Goujian in Twentieth-Century China, Berkeley (CA), University of California Press.

21. Harold L. Kahn, Monarchy in the Emperor's Eyes: Image and Reality in the Ch'ien-lung Reign, Cambridge (MA), Harvard University Press, 1971, p. 51.

22. In December 2007, the film enjoyed a limited re-release as part of a commemoration of the life and career of its female lead, Ruan Lingyu. For more on this, see my The Forbidden City, Cambridge (MA), Harvard University Press, 2008, pp. xxxi \& 100; and the online notes: http://ciw.anu.edu.au/ projects/theforbiddencity/notes.php?chapter=chapter5 (consulted on 11 May 2012).

23. Qianlong xia Jiangnan 乾隆下江南. The TV series was a co-production of the Beijing Film Studio TV Studio and Feiteng Film Company 北影电视部与飞腾电影公司. See also Zhao Zhizhong, "Da Qing wangchao re," in Fu Bo (ed.), Cong Xingjing dao Shengjing-Nu'er hachi jueqi guiji tanyuan, Shenyang, Liaoning minzu chubanshe, 2008, pp. 373-82. The "Fanciful Account of Qianlong" was soon followed by A Fanciful Account of the Empress Dowager (Xishuo Cixi 戏说慈禧).

24. See Q. Edward Wang, Inventing China Through History: The May Fourth Approach to Historiography, New York, State University of New York, 2001. 
and fiction accounts of both Republican and Communist Party history accord with guidelines set down by Party historians and propagandists. This policing of the past has been particularly prevalent since an incident in 2003 involving the multi-episode TV series, Towards a Republic 走向共和. Produced to mark the 1911 Xinhai Revolution and the founding of the Republic of China, the series was, at first glance, a relative standard costume drama, mixing as it did elements of theatricality with serious history. The writers of Towards a Republic, who included liberal Qing historians, offered a view of the 1911 Revolution that not only challenged the Party's interpretation of the past but also served as an indictment of its present autocratic behaviour.

The 60-part series had a finale in which the father of the nation, Sun Yat-sen, appears to be addressing the viewing audience directly. As he explains the symbolism of what we know as the Mao suit (Zhongshanzhuang or "Sun Yat-sen jacket" in Chinese), Sun describes each of the buttons and pockets of the garment as representing parts of his political program - economic progress, democratisation, and the separation of powers. He then addresses the viewer:

I have thought long and deep in recent times: how is it that so many feudalistic and autocratic things have appeared time and again in our new Republic? If this is not dealt with, it is inevitable that the autocracy will reign once more; the Republic will forever be but a mirage.

The idea of a Republic is based on equality, freedom, and the love of humanity. But over the past six years we have been witness to how government bureaucrats at every level have treated the law like dirt; how the people have been enslaved.

A Republic should be a place of freedom; freedom is the heavengiven right of the people.

But over these six years we have witnessed the power-holders enjoying freedom. The more power you have the more freedom you enjoy; the less power you have the more circumscribed your freedom. The people have no power, so they have no freedom...

The Republic should be governed by the rule of law, but over the past six years we have seen administrative power used repeatedly to interfere with the operation of the law. If you are not obedient I'll buy you off; if you fail to comply I will arrest you, or have you killed. Lawmakers have been prostituted by the power-holders, and they have their way at will... (25)

When the series was rebroadcast this material had been removed. As a result of the controversy surrounding Towards a Republic, in 2004 the State Administration of Radio, Film, and Television established a new oversight group that would now police the production and censoring of all materials related not only to the revolution but to history overall. (26) It was this same government group that in early 2011, as rumours and power-play swelled in Beijing and elsewhere, placed a ban on films and TV shows that speculated about either the past or the future. As political rumour-mongering unsettled Party equanimity, the possibility that people could contemplate alternative scenarios for China also seemed unsettling. In particular, shows featuring time travel (known as chuanyueju 穿越剧) were interdicted as they "lack positive thoughts and meaning" (27) and go "against Chinese heritage." (28)

As issues related to democracy and authoritarianism are debated today, we can also detect a nostalgia for a past in which a different kind of future was imagined, as opposed to a present in which the past is constantly being marshalled, trimmed, and massaged to legitimate the Party. As film and TV accounts of the past proliferated through the 1990s and into the new millennium, a new category of revived culture appeared, that of the "red classic" (hongse jingdian 红色经典). First promoted as part of the patriotic education campaign instituted following the events of 1989 to teach both students and wider audiences about the history of the revolution and the dangers that had, and that continued, to beset it, "red classics," or old propaganda movies, were rebroadcast nationwide. In more recent years as media offerings have proliferated, a new genre of culture has developed under the old rubric of the "red classic." These include not only films and TV shows, but also songs, novels, poems, and art works. Collectively they form a narrative of revolution that has been stripped of revolutionary politics but which retains a highly romantic depiction of the past and its achievements in which the glories of the Party are intertwined with accounts of heroism, love, sacrifice, and noble aspiration.

Until the appearance of the "sing red" campaign championed by Chongqing Party Secretary Bo Xilai and his supporters in 2009, the "red classic" genre was easily derided as being of marginal interest and importance in understanding contemporary China and its worldview. I would ask rather as series of questions:

Is the corpus of "red classic" works merely fodder for the avaricious maw of a media market that must work with the material available, and as such has little greater significance?

Or is it part of the very skein of modern mainland Chinese culture that through repetition and adaptation has normalised the historical narrative of the modern party-state? And, if that is the case (even partially),

Does the de-politicised narrative of the revolution not cannily employ petit-bourgeois sentimentality as a means to disallow audiences from imagining significant social change? ${ }^{29}$

Or is there some greater, more "progressive," potential in the repetition of familiar cultural "classics," so much so that in fact these works re-familiarise audiences with the revolution, its values, and rhetoric, so that concepts of social justice, fairness, and freedom that were so important during the long years of struggle before 1949 find a new lease on life?

Or should these concerns be swept aside as it is all just commercialised fun and a story about canny media players cynically taking advantage of party-state dictates to promote and produce uncontroversial material?

Is this yet another chapter in the degradation of the sublime (chonggao 崇高) that the novelist and former Minister of Culture Wang Meng 王蒙 decried in the 1990s?

Or, perhaps, can we detect in the re-makings, spoofs, and recountings of High Maoist policies, cultural styles, and forms ways in which the impotent, powerless, and dispossessed can express opposition to the eternalising pre-

25. For the scene, see: http://v.youku.com/v_show/id_XMTY3Njk2MDA=.html (consulted on 11 May 2012).

26. See Matthias Niedenführ, "Revising and Televising the Past in East Asia: 'History Soaps' in Mainland China," in Steffi Richter (ed.), Contested Views of a Common Past, Frankfurt/New York, Campus Verlag, 2008, pp. 351-69, at pp. 364-65.

27. See David Barboza, "Making TV Safer: Chinese Censors Crack Down on Time Travel," The New York Times, 12 April 2011, http://artsbeat.blogs.nytimes.com/2011/04/12/making-tv-safer-chinesecensors-crack-down-on-time-travel (consulted on 11 May 2012); and, for the Chinese document, www.sarft.gov.cn/articles/2011/03/31/20110331140820680073.html (consulted on 11 May 2012).

28. See "China banning time travel for TV?", http://business.blogs.cnn.com/2011/04/14/china-banstime-travel-for-television (consulted on 11 May 2012).

29. "De-politicised politics" is a term grafted from the work of Wang Hui. See also Yang Jinhong, "Man tan 'hongse jingdian' gaibian," at: http://qkzz.net/article/f3ab77dg-5b11-4cfa-9b16050c70ada9d7.htm (consulted on 11 May 2012). 
sumption of a party-state, one that maintains its dominion over the mainstream historical narrative, national identity, and real political power?

Is this "resistance within" also not part of the red legacy - the opposition to the Party's theory-led monopoly on discourse, ideas, and everyday politics?

\section{Waving the red flag to oppose the red flag: Red heirs and intellectuals}

History, distorted accounts of the past, and the power of metaphor have all played a role in the unfolding of recent Chinese political dramas, just as they have engaged with the Maoist legacy in complex ways.

In April 1984, a group of students who had graduated from elite Beijing middle schools created an informal association to celebrate their camaraderie and their origins. They called themselves the Fellowship of the Children of New China (Xinhua Ernü Lianyihui 新华儿女联谊会). ${ }^{(30)}$ At the time of the centenary of Mao Zedong's birth in 1993, the group renamed itself the Beijing Children of Yan'an Classmates Fellowship (Beijing Yan'an Ernü Xiaoyou Lianyihui 北京延安儿女校友联谊会). Its members were the descendants of men and women who had lived and worked in the Yan'an Communist base in Shaanxi Province from the 1930s to the 1940s, as well as the progeny of the Party who were born and educated in Yan'an. From 1998, the group held annual gatherings to coincide with the Spring Festival (Chinese New Year), as well as a range of other events organised around choral and dancing groups, Taijiquan classes, and painting and calligraphy activities. In 2001, they shortened their name to the Beijing Children of Yan'an Fellowship.

From 2002, the Children of Yan'an was led by Hu Muying 胡木英, daughter of Hu Qiaomu 胡乔木, a Party wordsmith par excellence and Mao Zedong's one-time political secretary. In 2008, the fellowship expanded its membership to include people with no specific link to the old Communist base and its revolutionary éclat. With a core membership of some 100 people, the Children of Yan'an not only boasted the leadership of Hu Muying, but also the key participation of Li Min 李敏 (Mao Zedong's oldest daughter), Zhou Bingde 周秉德 (Zhou Enlai's niece), Ren Yuanfang 任远芳 (Party elder Ren Bishi's 任嵊时 daughter), Lu Jianjian 陆健健 (former Party propaganda chief Lu Dingyi's 陆定一 son) and Chen Haosu 陈昊苏 (son of Chen Yi 陈毅, the pre-Cultural Revolution Mayor of Shanghai and later Minister of Foreign Affairs). On 13 February 2011, the group held their annual Chinese New Year gathering in the auditorium of the 1 August Film Studio, an organisation under the direct aegis of the People's Liberation Army.

On that occasion, apart from the Children of Yan'an, a range of other interested groups, or what were dubbed "revolutionary mass organisations," were also present. ${ }^{(31)}$ During the speech-ifying that day these various attendees were collectively represented by Chen Haosu, himself a former film and TV bureaucrat with a noble Party lineage that we have noted above. The Children of Yan'an Fellowship itself was represented by Hu Muying and her deputy, Zhang Ya'nan 张亚南, formerly the Political Commissar of the PLA Logistics Department and previously secretary to Wei Guoging 韦国清, a Cultural Revolutionera vice-chairman of the National People's Congress.

Following a series of platitudinous remarks and a brief recounting of the long years of struggle that their revolutionary forebears had gone through to found New China (an account that, not surprisingly, glossed over the bloody horrors of the first three decades of Party rule from 1949 to 1978), Hu Muying said:

The new explorations made possible by Reform and the Open Door

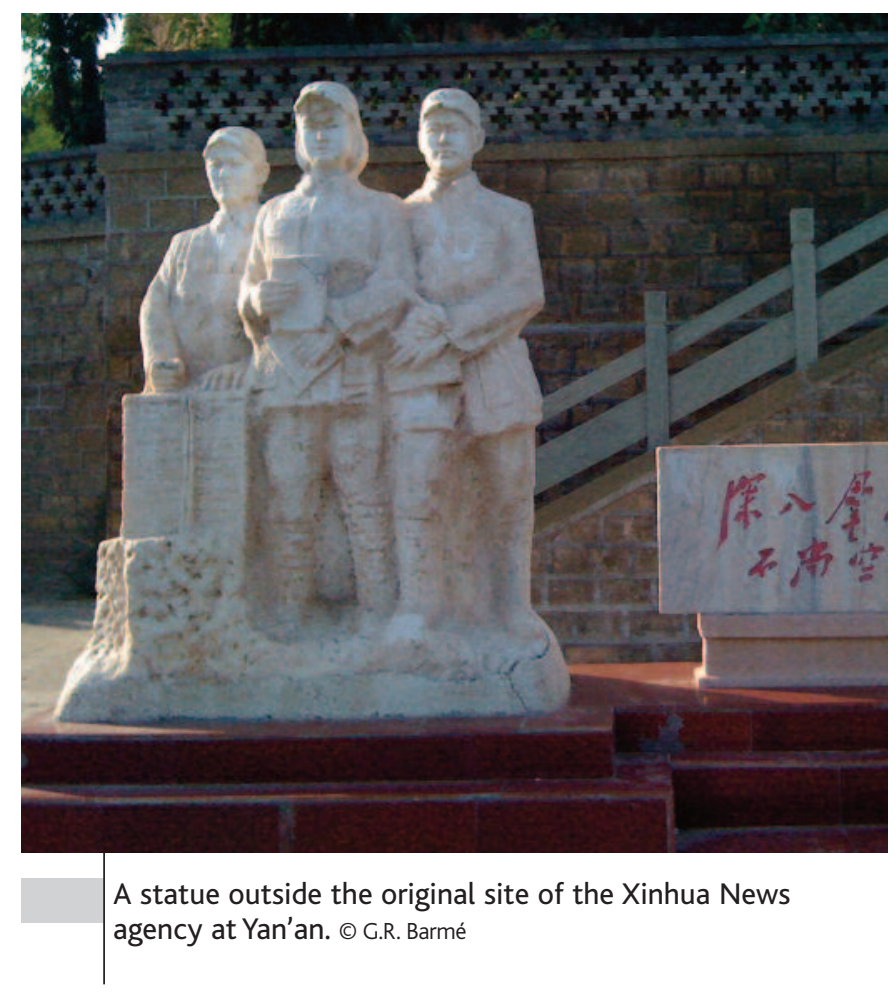

policies have, over the past three decades, resulted in remarkable economic results. At the same time, ideological confusion has reigned and the country has been awash in intellectual currents that negate Mao Zedong Thought and socialism. Corruption and the disparity between the wealthy and the poor are of increasingly serious concern; latent social contradictions are becoming more extreme.

We absolutely reject the label of "Princelings" (Taizi Dang 太子党), nor are we "Second-generation Bureaucrats" (Guan Erdai 官二代). We are the Red Successors, the Revolutionary Progeny, and as such we cannot but be concerned about the fate of our Party, our Nation, and our People. We can no longer ignore the present crisis of the Party. (32)

Hu went on to say that through the activities of study groups, lecture series, and symposia the Children of Yan'an had formulated a document that, following broad-based consultation, would be presented to Party Central. The document was entitled "Our Suggestions for the Eighteenth Party Congress" (Women dui Shiba Da de jianyi 我们对十八大的建议). (33) "We cannot," Hu continued:

30. This overview is based on material available at the Children of Yan'an website. See: www.yananernv.cn/geren.html (consulted on 11 May 2012).

31. These groups included: New Fourth Route Army Research Group 新四军研究会, The Children of Jinggang Shan 井冈山儿女联谊会, The 1 October Classmates Society 十一同学会, The Children of Red Crag 红岩儿女联谊会, The Association of the Western Flower Pavilion 西花厅联谊会, Beijing Eighth Route Army Anti-Japanese Shandong Base Research Society 北京八路军山东抗 日根据地研究会, Transmitters of the Taiyue Mountains Tradition Group 太岳精神传承会, Children of the War of Resistance University 抗联儿女联谊会, Mid-Hebei Research Group 冀中研 究会, The Children of the West Route Army Group (preparatory committee) 西路军儿女联谊会 筹备组, Nation Founding Marshalls Choral Society 开国元勋合唱团, Beijing 1 October Classmates Club 北京十一同学会, 101 Middle School Club 101 中同学会, Yucai Middle School Club 育才同学会, 1 August Classmates Club 八一同学会, North China Primary School Club 华北小 学同学会, and the Yuying School Club 育英学校同学会. All of them boast complex backgrounds, affiliations, and party-state-army connections.

32. For Hu's speech, see: "Hu Muying huizhang 2 yue 13 ri zai Yan'an ernü lianyihui tuanbai dahui shangde zhici," online at: www.yananernv.cn/news_2425.html (consulted on 11 May 2012).

33. For details, see: www.yananernv.cn/news_2427.html (consulted on 11 May 2012). 


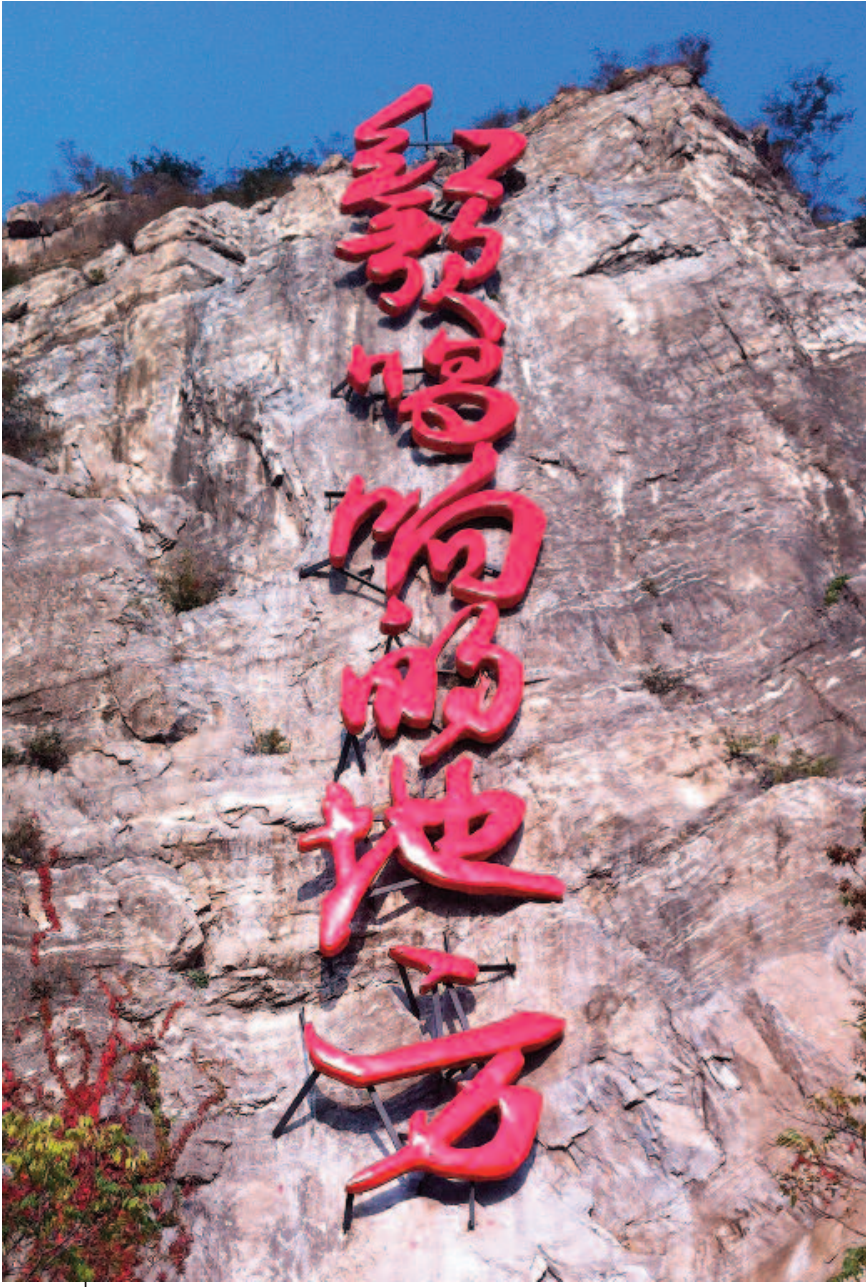

'The place where the red songs started being sung'-Xiayun Ling, Hebei 河北省霞云岭.

(c) G.R. Barmé

be satisfied merely with reminiscences nor can we wallow in nostalgia for the glories of the sufferings of our parents' generation. We must carry on in their heroic spirit, contemplate and forge ahead by asking ever-new questions that respond to the new situations with which we are confronted. We must attempt to address these questions and contribute to the healthy growth of our Party and help prevent our People once more from eating the bitterness of the capitalist past.

For his part, Zhang Ya'nan declared that China's Communist Party, the Communist cause, and Marxism-Leninism itself were being directly challenged and indeed disparaged by the enemies of the revolutionary founding fathers. In particular, he despaired of the de-Maoification that continued to unfold in China. He reminded his audience that "Chairman Mao bequeathed us four things: one piece of software and three pieces of hardware. The hardware is the Chinese Communist Party, the Chinese People's Liberation Army, and the People's Republic of China. The software is Mao Zedong Thought." Zhang went on to praise the Red Culture campaign launched by Bo Xilai in Chongqing in 2008, the stance of Major-General Luo Yuan 罗援, and the writings of Zhang Tieshan 张铁山. He then commended to his audience the document formulated for the Party's late-2012 Eighteenth Congress. He declared that it was a manifesto that gave voice to their wish "to love the Party, protect the flag, and revitalise the as-yet-unfinished enterprise of our revolutionary forebears." He also suggested that the Children of Yan'an should invite activists who were involved in the Mao Zedong Banner website 毛泽东旗帜网 and the Workers' Network 工人网 to their next Spring Festival gathering in January 2012. ${ }^{(34)}$

The Children of Yan'an site made no mention of the 2012 Spring Festival, which, in the event, was a low-key affair. After all, as we have noted above, by then the "atmospherics" of Chinese politics had undergone a dramatic transformation. Not long after Spring Festival, Wang Lijun had made his dramatic visit to the American Consulate in Chengdu. By mid-March, around the time of Bo Xilai's fall, key leftist or revivalist-Maoist sites such as Utopia, Mao Zedong Banner (Mao Flag), and Red China had been suspended by the authorities; Workers' Network, however, remained active. ${ }^{(35)}$ One could summarise the views of this informal comradely coalition, one that is based both in China and overseas, in the following terms: China's party-state system (from the Party, army, and government bureaucracy, through to the legal system and academia) has for the most part fallen under the control of agents who in the long run are working for foreign interests; the mainstream Chinese elite consists of pro-US agents. In response to the incursions of global capital, it was necessary to re-nationalise all assets and abolish private enterprise and the non-state private market, as well as to reinstitute central planning. By and large, these groups reaffirm the importance of class analysis and class struggle, as in the nation's political life, some declare, it was once more necessary to obliterate "bourgeois elements taking the capitalist road" in all areas of government. Among other things, some called for a reform of China's legal system so that the death penalty could be extended to intellectual "traitors." They obliged the authorities by compiling a list of writers, editors, and intellectuals who would be candidates for elimination. ${ }^{36)}$

With their gaze fixed more on the past than the present, the drafters of "Our Suggestions for the Eighteenth Party Congress" reaffirmed the primacy of what is known as the "mass line" (qunzhong luxian 群众路线). First articulated by Mao as early as 1929, the mass line is regarded as being one of the foundations of Mao Zedong Thought. It calls for the Party to rely un-

34. For Zhang Ya'nan's speech, see "Chunjie tuanbaihui zhuchici (zhailu)," online at: www.yana nernv.cn/news_2428.html (consulted on 11 May 2012). The "de-Maoification" referred to by Zhang was actually a formal process launched by the Chinese Communist Party in the late 1970s. In recent years, however, more detailed critiques of Mao and his period of rule have been published by those with less sympathy for the Communist cause. One of the most recent of these appeared in April 2011, some two months after Zhang Ya'nan's handwringing. It was by the academic Mao Yushi 茅于轼: "Make Mao human once more - On reading The Sun Also Falls" (Ba Mao Zedong huanyuan chengren - du Hong taiyangde yunluo), online at: http://china.dwnews.com/ news/2011-04-26/57658778.html (consulted on 11 May 2012).

35. See Robert Foyle Hunwick, "Utopia website shutdown: Interview with Fan Jinggang," 14 April 2012 on Danwei, online at: www.danwei.com/interview-before-a-gagging-order-fan-jinggang-of-utopia (consulted on 11 May 2012). See also: http://maopai.net (consulted on 11 May 2012).

36. On 28 December 2011, the Maoist revanchist site Utopia published the results of a year-end poll on China's top traitors (乌有之乡: 评选'十大文化汉奸'). The CIW-Danwei Online Archive project provided this news and the decoded list originally published as www.wyzxsx.com/Article/ Class22/201112/284230.html, now no longer available (see instead the Editor's Introduction to A View of the Hero Yue Fei and the Traitor Qin Gui 岳飛與秦檜, at: http://www.chinaheritagequarterly.org/features.php? searchterm=028_yuefei.inc\&issue=028). The nominees in infamy were: 1. Economist Mao Yushi茅于轼; 2. History teacher Yuan Tengfei袁腾飞; 3. Science cop (antiChinese medicine, etc.) Fang Zhouzi 方舟子; 4. Economist Wu Jinglian 吴敬牫; 5. Diplomat Wu Jianmin 吴建民; 6. CCTV host Bai Yansong 白岩松; 7. Military scholar, Mao Zedong and Lin Biao biographer Xin Ziling辛子陵; 8. Retired government official/ reformer Li Rui李锐; 9. Legal scholar/law professor He Weifang 贺卫方; 10. Economist Stephen N. S. Cheung 张五常; 11. Economist Zhang Weiying 张维迎; 12. Economist LiYining 厉以宁; 13. Southern Weekly deputy general editor Xiang Xi 向喜; 14. Former People's Daily deputy editor-in-chief Huang Fuping 皇甫平; 15. Writer and Nobel Prize-winning dissident Liu Xiaobo 刘晓波; 16. Former Mao doctor, Mao biographer Li Zhisui李志绥 (deceased); 17. Peking University journalism professor Jiao Guobiao 焦国 标; and, 18. Former People's Daily editor-in-chief/publisher Hu Jiwei 胡绩伟.

37. A line from Mao's famous 1966 "Letter to liang Qing" (Mao Zedong zhi liang Qing deyi fengxin), officially dated 8 July, although it is highly doubtful that the letter that was released following Lin Biao's demise in September 1971 was actually composed in 1966. 
waveringly on the masses (a vague and ill-defined group at the best of times), to put faith in them, arouse them, go among them, honestly learn from them, and serve them.

The Children of Yan'an declared that their reform proposals were a practical realisation of the long-standing principle of the mass line, one that was enshrined in the Party's Constitution and which had in the past ensured the Party's successes. Moreover, they declared that Party leaders could ill afford to use social and political stability as an excuse for further delays to the substantive reform of China's political system. The Children of Yan'an declared that new political talent could be found among the masses, in particular among the enthusiastic Party faithful. They claimed, for instance, that the Red Song movement that originated in Chongqing, and which later spread nationwide, had seen the appearance of just the kind of enthusiastic younger Party members who would help ensure the continuation of the Communist enterprise far into the future. On the eve of the Cultural Revolution in 1966, Mao Zedong is said to have cautioned that after his demise people would inevitably "wave the red flag to oppose the red flag" (da hongqi fan hongqi 打红旗反红旗). ${ }^{(37)}$ Now it would appear that the Children of Yan'an were using their very own red flag to oppose the red flag of economic reform that, since 1978, had been employed to oppose the red flag of Maoism. This was one of the underpinnings of Zhang Musheng's 张木生 re-reading of the Party's 1940s program related to "New Democracy" formulated by Mao Zedong-Liu Shaoqi, one that attempted to reconcile Party traditionalists with the desire for political reforms in keeping with the original ethos of the Mao years (see also Sebastian Veg's contribution to this issue). (38)

The revival of a patriotic-oriented Maoist "Red Culture" in Chongqing under Bo Xilai would for a time be affirmed (or was it really to be co-opted and marginalised?) by Party leaders, in particular by Politburo Standing Committee member and head of the party-state legal establishment Zhou Yongkang 周永康. Around the time that Bo Xilai led a delegation of "red songsters" to Beijing in mid June 2011, Zhou called for the "forging of three million idealistic and disciplined souls who are ready to face all dangers with an unwavering faith." Of importance in the crucible of the engineers of human souls was what would now be called the "Five Reds," that is, "Reading red books, studying red history, singing red songs, watching red movies, and taking the red path." (39)

Not only did the Children of Yan'an formulate a manifesto and agitate for a form of political reform before the looming change of Party leadership; it was further said that in their pursuit of a new Maoist-style "mass line" they had also tried to engender tentative contacts with grass-roots organisations and petitioner groups in and outside of Beijing. For left-leaning figures in contemporary China to engage in such practical, and non-hierarchical, politics was highly significant, especially when considered in contrast to the academic "New Left" (Xinzuopai 新左派) that had arisen in the 1990s and 2000s.

For over a decade the "New Left" intellectuals - a disparate group that, like their rhetorical opponents, the "Liberals," was generally lumped together - had been variously celebrated and derided. In the late 1990s I spoke about the "confrontation of caricatures" - that between "new left" and "liberal" that was polarising the Chinese intellectual world. ${ }^{(40)}$ It is a topic that the intellectual historian Xu jilin 许纪霖 has frequently addressed since that time. (41) The critics of the New Left claimed that they were primarily "onpaper generals" (zhishang tan bing 纸上谈兵) who could talk up a storm (both in China and at the various international academic fora to which they are frequently invited). They may well profess themselves to being intellec- tually committed to "recuperating" radical socio-political agendas, critiquing the capitalist turn in China, and thinking of how best to utilise the "resources" of Marxism-Maoism in the context of the reform era. To their critics, members of the New Left rarely seemed to demonstrate any practicable desire to deal with the deprived, marginalised, dispossessed, or repressed individuals in the society as a whole. Their critics also noted that when issues of free speech or intellectual freedom came up this usually vociferous group was generally silent. ${ }^{(42)}$ While elite members of this leftist claque formed meaty alliances with their global intellectual coevals, on the ground in China protest, resistance, and opposition to the oppressive practices of party-capitalism remained the province of lone activists, NGO groups, liberal intellectuals, lawyers, and the woefully "under-theorised."

Not only was the revivalism of Chongqing appealing to the Children of Yan'an, it also attracted a range of left-leaning or New Left intellectuals both in and outside of China. Bo Xilai and his circle actively cultivated this disparate group through targeted support for seminars, conferences, and other generously funded activities. As has been the case of intellectuals attracted moth-like to the flame of power in the past, many of these individuals with their myopic attachment to theory convinced themselves and others to overlook the evidence in front of them. However, the purblindness and reticence of members of the New Left is, perhaps, also understandable. Apart from the usual intellectual qualms about direct social engagement among those who are more comfortable dealing with academic jousting and refereed publications in prestigious journals, in China principled activism does exact a high price. After all, the engaged intellectual soon confronts a policed authoritarian environment that is infamously punitive. Moreover, the fate of such prominent nay-sayers as Liu Xiaobo 刘晓波 and Ai Weiwei 艾末末 would deter all but the most foolhardy. More disturbing yet is the cruel abuse of numerous (and often nameless) men and women of conscience who have been harried, detained, and persecuted by local powerholders and business interests for often the most spurious reasons. One of the issues that this paper returns to in various guises is the question of whether a pro-Maoist rhetoric is the only form of left-leaning critique available to Chinese thinkers and their international supporters. And, if that is the case, are critiques of Mao and his bloody legacy always to be deemed as orientalist, reactionary, or pro-neo-liberal?

38. Here one is reminded of Wang Shuo's 1989 novel, No Man's Land (Qianwan bie ba wo dang ren). In one scene the protagonist falls in with a leftist underground study group that discusses official corruption, the need for workers' rights, and for another revolution. The group is broken up by the authorities, who declare that they are escapees from a mental asylum. As the later-day Trotskyites are being dragged away, one shouts out: "What are you going to do when the [real] Communists come back?" See "The Apotheosis of a Liumang" in my In the Red, op. cit., pp. 91-92.

39. For the Chongqing Daily online report, see "(Chongqing) Zhonghua hongge huilong zhong kaimu" at: http://news.online.cq.cn/chongqing/2011/06/30/3350893.html (consulted on 11 May 2012). For those interested in another form of realpolitik, it is perhaps also noteworthy that the "old friend of China," Henry Kissinger, attended the rally. Around the time of Bo Xilai's demise the fate of his presumed Politburo patron, Zhou Yongkang, was much discussed.

40. Barmé, "The Revolution of Resistance," in Elizabeth J. Perry and Mark Selden (eds.), Chinese Society: Change, Conflict and Resistance, 3rd ed., London, Routledge, 2010.

41. See, for instance, Xu Jilin, "Jin shinian lai Zhongguo guojiazhuyi sichaozhi pipan," posted on 6 July 2011 online at: www.21ccom.net/articles/sxpl/sx/article_2011070638713.html (consulted on 11 May 2012).

42. See Cui Weiping's 崔卫平 phone and email interviews published via Twitter, "Cui Weiping jiu Liu Xiaobo an fangtan Zhongguo zhishifenzi," now available at: http://xiangeliushui.blogspot.com.au/ 2009/12/cuiwenping-interview-about-liuxiaobo.html (consulted on 15 May 2012), and my comment in "China's Promise," China Beat, 20 January 2010, at: www.thechinabeat.org/?p=1374 (consulted on 11 May 2012).

43. Andre Aciman, "Arbitrage," The New Yorker, 10 July 2000, p. 36. This material on arbitrage first appeared in my chapter "Time's Arrows: Imaginative Pasts and Nostalgic Futures," in Cloria Davies (ed.), Voicing Concerns: Contemporary Chinese critical inquiry, Boulder (CO), Rowman \& Littlefield, 2001. 


\section{Arbitrage: The global trade in red rhetoric}

In discussing red legacies it is necessary to be mindful of the long tradition whereby left-leaning causes, and discourse, in China (not to mention elsewhere) have been entwined with a nationalist or patriotic mission related to independence, economic growth, and identity politics. In the context of legacy-creation, the Chinese party-state has inherited and invested heavily in the Maoist heritage by transposing social class analysis and the Threeworld Theory into the context of contemporary geopolitics. Thus, the People's Republic, despite its regnant economic strength and international heft, portrays itself as a proletarian-agrarian developing nation that is primarily in solidarity with the dispossessed and under-developed nations against the bourgeois bullies of Euramerica. No matter what elements of truth this selfdescription may have, as a rhetorical device and canny transmogrification of High Maoist categories, it remains a powerful tool in global power politics, and one area in which the Maoist legacy is particularly vital, and successful.

The trans-valuation of Maoist categories into international relations discourse is only one of the ways in which the heritage persists into the present. Another is the way that rejigged elements of the Maoist canon are employed to bolster careers, to align research projects, and to guide personal trajectories. (I would observe that the same holds true even for those who use Maoist-style patriotism to pursue neo-liberal goals, be they academic or mercantile.)

In the late 1990s, a disparate group that I think of as the interrogators of the intelligentsia set themselves apart from the restive throng of their educated fellows by claiming a unique purchase on critical inquiry. In their writings they pursued a project of visualisation towards a "China imaginary" that would cast all liberal (and I don't mean neo-liberal) intellectuals as being of one cloth. As we consider the varied roles of participant observers, theorising nonactivists, and academic middlemen (among whose number I would, of course, include myself), a term current in the world of international finance suggests itself. It is called "arbitrage," that is, "the purchase of securities in one market for resale in another." As Andre Aciman comments on the practice in terms of nostalgia and time:

As soon as a profit is made, the cycle starts again, with subsequent purchases sometimes paid for with unrealized profit drawn from previous sales. In such transactions, one never really sells a commodity, much less takes delivery of anything. One merely speculates, and seldom does any of it have anything to do with the real world. Arbitrageurs may have seats on not one but two exchanges, the way the very wealthy have homes in not one but two time zones, or exiles two homes in the wrong places. One always longs for the other home, but home, as one learns soon enough, is a place where one imagines or remembers other homes. ${ }^{(43)}$

In the context of our own academic pursuits, while one can appreciate divergent agendas for intellectuals who practice their armchair activism in the relatively oblique language of the academy, an accounting for the past requires an approach that is mindful not only of frustrated political agendas and the failure of ideas in practice, but also of the complex human dimension of ideas in social practice.

In his study and summation of Leszek Kołakowski's monumental world Main Currents of Marxism, Tony Judt in particular identifies the abiding at- traction of that political philosophy: its "blend of Promethean Romantic illusion and uncompromising historical determinism." (44) Marxism thus, in this account,

...offered an explanation of how the world works... It proposed a way in which the world ought to work... And it announced incontrovertible grounds for believing that things will work that way in the future, thanks to a set of assertions about historical necessity... This combination of economic description, moral prescription, and political prediction proved intensely seductive - and serviceable. ${ }^{(45)}$

We may well speak of the clever commercialisation of China's red legacy, the canny ways in which elements of the Mao era are insinuated into contemporary political, social, and cultural discourse. Some writers and commentators are even still diverted by the tired uses of socialist irony in culture (art, film, essays, blogs, literature, and so on). Others may be beguiled by the latest in a long line of attempts to recuperate Marx or indeed Mao himself from "distortion," or the academic subprime market devoted to holistic, globalising interpretations of the Marx-Engels-Lenin-Stalin-Mao project. In terms of activism, one legacy of the revolutionary Mao era - that of direct political involvement, organised resistance, and struggle, however, seems to be less appealing. ${ }^{(46)}$

It is here then, perhaps, that the post-Maoist, Marxist turn in China contributes to our understanding of the categories of the Maoist or red legacy in the new millennium. Needless to say, much can be made of the glib (and cynical) commercialisation of red tourism, of the audio-video and digital wallpaper generated in various cultural forms that quote, revive, and cannibalise works of high-socialist culture. But has the continuation of one-party rule in China achieved something particular, not merely the Party as a particular Chinese phenomenon, and therefore regarded as only being on a national mission of "prosperity and strength," but also something else? I would ask whether the language of the red legacy and its various manifestations are merely a sly way of packaging Chinese materialism and worldliness, or whether there might be more at stake and more inherent in it.

While thinkers labour to salvage Marxism from the egregious failures, and crimes, of Communism (be they of the Soviet or the Maoist variety), the red legacy is no cutesy epiphenomena worthy simply of a cultural studies or po-mo reading, but rather constitutes a body of linguistic and intellectual practices that are profoundly ingrained in institutional behaviour and the bricks and mortar of scholastic and cultural legitimisation. The on-theground reality of the People's Republic is that topics couched in MarxistMaoist terminology remain privileged within Chinese educational institutions, among publishers, think tanks, and funding agencies. It is a living legacy the spectre of which continues to hover over Chinese intellectual life, be it for weal or for bane. And, as I have pointed out in the above, it is

44. Tony Judt, "Goodbye to All That? Leszek Kołakowski and the Marxist Legacy," in Reappraisals, Reflections on the Forgotten Twentieth Century, New York, The Penguin Press, 2008, p. 133.

45. Ibid.

46. Perhaps we may recall that Kołakowski's scathing observation of the pursuit of Marxism by Euramerican intellectuals and academics: "One of the causes of the popularity of Marxism among educated people was the fact that in its simple form it was very easy.....an instrument that made it possible to master all of history and economics without actually having to study either." (Judt, "Goodbye to All That?", op. cit., p. 135.)

47. From Ari Daniel Levine, Divided by a Common Language: Factional Conflict in Late Northern Song China, Honolulu: University of Hawai'i Press, 2008, pp. 49-50. For a somewhat different version of Ouyang's essay, and a lengthy discussion, see also James T.C. Liu, Ou-yang Hsiu: An EleventhCentury Neo-Confucianist, Stanford: Stanford University Press, 1967, pp. $53 \mathrm{ff}$ 
worth asking whether this particular red legacy does in fact leech out the power of other modes of left-leaning critique and independent thought, and only aid and abet the party-state's pursuit of a neo-liberal economic agenda.

\section{Fellowships and factions}

In 1044 CE, the Song-dynasty political figure and writer Ouyang Xiu 欧阳修 submitted a memorial to the throne entitled "On Factions" (Pengdanglun 朋党论). In it he argued against the long-standing taboo on coalitions in government. He suggested to the throne that political groupings of likeminded men working for the benefit of the court and its dynastic subjects were in fact a constructive development. Regarded as the most famous argument in favour of political alliances in Chinese history, "On Factions" has resonated through the ages.

In his memorial Ouyang said:

Thus, Your servant claims that petty men are without factions and that only superior men have them. Why is this so? Official salaries and gain are what petty men enjoy; wealth and goods are what petty men covet. When they seek mutual gain, they will temporarily form an affiliation (dang), but it is erroneous to consider them to be a faction (peng). When they glimpse gain and contend to be first [to take it], or when the gains have been exhausted, and they squabble over what remains, then they will cruelly injure each other. Even if they are brothers or kinsmen, they will not be able to protect each other.

然臣谓小人无朋，惟君子有之。其故何哉? 小人所好者利禄也，所 贪者财货也; 当其同利时, 暂相党引以为朋者, 伪也。及其见利而 争先, 或利尽而交疏, 则反相赋害, 虽其兄弟亲戚, 不能相保。故 臣谓小人无朋, 其暂为朋者, 伪也。

...this is not so for superior men. The Way and righteousness are what they defend; loyalty and sincerity are what they practice; and reputation and integrity are what they value. Since they have cultivated themselves, their common Way (tongdao) is of mutual benefit. Since they serve the polity, their common hearts help each other, and they are always as one. Such are the affiliations of superior men.

君子则不然。所守者道义, 所形者忠义, 所惜者名节; 以之修身, 则同道而相益, 以之事国, 则同心而共济, 终始如一。此君子之朋 也。(47)

Mao Zedong was notorious for construing those with political differences as being members of dangerous factions and alliances. He frequently warned against the dangers of "cliques" (zongpai 宗派); he demonised his perceived rivals as pursuing a political line invidious to the Chinese revolution, and he was merciless first in toying with and then obliterating those whom he suspected of having formed alliances in opposition to him. Differences in policy, strategy, and even personality were depicted as "line struggles" (luxian douzheng 路线斗争), and for decades the history of modern China as accounted by the Communist Party was a record of such struggles.

In the landscape of authoritarian Chinese politics there has occasionally been an attempt to recognise, if not formalise, the role of a "loyal opposition" in government. In the history of the Chinese Communist Party, which celebrated its ninetieth anniversary on 1 July 2011, inner party factions were outlawed, often in the most violent manner. Although the Chinese Communist Party may well maintain that China in the twenty-first century is led by one party in coalition with other "democratic parties" (minzhu dangpai 民主党派) that contribute to the political process, the reality is that no quarter is given to formal oppositionist politics.

In the realm of media and Internet contention, discussion in China is more free-wheeling in many regards than during other periods of Party rule. Today, however, major differences in policy are papered over or suppressed under the guise of collective leadership. Line struggles are a Maoist relic; in their place there is talk of "Party discipline" (dangji 党纪) and "state law" (guofa 国法). Whatever his disciplinary infractions or criminal misdeeds, Bo Xilai is seen by some as being the victim of a Party "line struggle" aimed at purging not only Bo and his associates, but even gestures towards a Maoist-era form of egalitarianism. Ideological contestation has been occluded by a formalistic legal process. There is already talk of a "show trial."

The historian F.W. Mote offered the following observation on Ouyang Xiu's Song-dynasty memorial and the problems that it highlighted for future generations. Mote's comment is relevant to a discussion of political contestation under authoritarian rule in China even today:

The failure of Neo-Confucian thinkers and political activists to break through this formal barrier against concerted political action by groups of like-minded men, by disallowing any distinction between good and bad factions, severely limited Chinese political behavior thereafter, up to the end of the imperial era in the early twentieth century... The attempt to redefine "factions" would arise again and again, up to the eighteenth century, but the state's definition always prevailed. Legitimate political parties could not take form, and any who expressed political disagreements were, by definition, morally defective, hence insidious. "Loyal opposition" could not be acknowledged within a system of politics defined by ethical and personal rather than by operational and institutional norms. China still struggles with the heritage of this eleventh-century political failure. ${ }^{(48)}$

\section{A crimson blindfold}

During the "history wars" in Australia that stretched out for a decade from the mid 1990s, historians who brought to light through their research unpalatable truths about the ugly colonisation of the country and the devastation of its indigenous population were condemned by government leaders, right-wing media commentators, and others claiming objectivity. The concerned historians were derided for promoting a "black armband" view of the past. Their historical perspective, one that by its very nature encouraged a heartfelt recognition of a complex history of settlement and a thoughtful reflection on its impact on the present, was seen as being a threat to national cohesion and more uplifting narratives of progress and modernity. The power-holders and their media supporters were in turn chided for

48. F. W. Mote, Imperial China 900-1800, Cambridge (MA), Harvard University Press, 1999, p. 137. See also my "The Children of Yan'an: New Words of Warning to a Prosperous Age 盛世新危言," at: www.chinaheritagequarterly.org/features.php? searchterm=026_yanan.inc\&issue=026 (consulted on 11 May 2012). 
championing a "white blindfold" view of the national story. In China, the blindfold is of a crimson hue.

Cosy theorising regarding a supposedly retrievable red legacy enjoyed a regional boost during the short-lived "red renaissance" championed by Bo Xilai and his supporters (political, military, and academic) until early 2012. His ouster does not mean, however, that red culture is defunct. Some of the motivating ideas, sentiments, and emotions of the Chinese revolution remain part of the fabric of life, and they find different levels of articulation and resonance in society. To appreciate more cogently the valency of China's red-suffused heritage, the overlay and interplay of historical tropes, language, practices, and evocations is, as I have argued in the above, important for an appreciation of the multifaceted commerce between past and present, traditions real and invented, and the evolution of contemporary ways of being, seeing, and speaking in that country today.

Even in power Mao Zedong frequently spoke about the dangers of bourgeois restoration and revisionism. He declared on a number of occasions that he would have to go back into the mountains to lead a guerrilla war against the power-holders, that rebellion was justified. While many discuss the legacy of revolutionary politics in the cloistered security of academic fora, that spirit of rebellion, the active involvement with a politics of agitation, action, and danger, is one legacy that seems only safe to contemplate at a distance. Restive farmers and workers in China may cloak themselves in the language of defunct revolution, but evidence suggests that rather than the crude categories of class struggle and revolutionary vanguards, their metaphorical landscape is a complex mixture of traditional cultural tropes, revolutionary discourse, and an awareness of modern rights and ways to stretch social rules.

As we consider the steely determinism of the Marxist lesson, we can detect how that historical determinism dovetails with articulations of a Chinese "national mission" today. The necessity of history remains at the heart of many attempts to find a more capacious meaning within the red legacy. Indeed, as we consider the long tail of Maoism both in and outside of the People's Republic of China, we should be alert to the abiding allure and uses of the crimson blindfold. After all, it is because of its nature as a belief system - as a body of thought, practice, language, and cultural heritage - that it forms part of China's red legacy, a system that has proved serviceable in the past and one that remains seductive, and useful, today.

I Geremie R. Barmé, founding director of the Australian Centre on China in the World (CIW) at The Australian National University and author of many books, is the editor of the web-journal China Heritage Quarterly (www.chinaheritagequarterly.org). 